\title{
Autoritarismo e transição
}

\author{
Paulo Sérgio Pinheiro
}

\begin{abstract}
Um regime inumano estende e alarga sua inumanidade em todas as direções, também e em especial para baixo.
\end{abstract}

(Primo Levi)

Depois do final das ditaduras dos anos 1980, os novos regimes políticos se confrontaram com o desafio de exercer o monopólio da violência do Estado dentro de padrões de legalidade. Esses apontamentos desenvolvem algumas observações preliminares sobre o controle das práticas arbitrárias por parte dos agentes do Estado e da violência ilegal nas interações entre os cidadãos nas transições políticas e sob os governos democráticos que delas emergiram. Nos pretendemos demonstrar que em alguns casos - como o Brasil - esses governos não conseguiram assegurar um dos requisitos básicos da sociedade democrática: o controle da violência.

Damos atenção aqui ao legado do autoritarismo e enfrentamos algumas questões como: que elementos do padrão de violência depois das transições políticas pertencem ao legado do regime de exceção? Que elementos podem ser explicados pela reprodução da estrutura tradicional de dominação e de poder? Quais os aspectos desse padrão que foram reforçados pelos governos autoritários?

Contemplamos aqui as diferentes maneiras através das quais $o$ Estado tradicionalmente assegura a sua hegemonia, especialmente quanto à substituição (ou complementação) da violência física, pela violence douce, por controles ideológicos. A violência ilegal do Estado e a impunidade da violência por parte dos cidadãos continua depois das transições políticas, mascarada pela retórica democrática, dissimulando relações fundamentais de força intocadas. As "instituições da violência" (Franco Basaglia), como a tortura, o racismo, as instituições totais - prisões e manicômios -, os aparelhos repressivos, não são transformados pelas transições, mesmo depois de constituições democráticas. Essas instituições, como antes das transições e depois delas, continuam a ter o mesmo papel relevante para a reprodução da dominação hierárquica em sociedades extremamente desiguais, como a brasileira.

Nessa análise das relações entre transição política e violência propomos ir além das instituições macropolíticas e levar em conta as microdimensões do poder, as microcenas onde ocorrem as interações concretas entre as pessoas na sociedade. Queremos abrir a discussão para algumas abordagens em microssociologia e encontrar instrumentos analíticos que possam ajudar a pesquisa a ultrapassar a ênfase na abordagem institucional macropolítica das análises da transição, para entendermos os microdespotismos que sobrevivem depois das ditaduras.
PAULO SÉRGIO PINHEIRO \& professor de Ciência Poltica na Universidade de Săo Paulo e diretor do Núcleo de Estudos da Violência-USP. Seu próximo livro, As estratégias da ilusão (a Revoluçáo Mundial e o Brasil, 1922-1935), sairá pela Companhia das Letras em maio de 1991. 
Em muitas sociedades, como a brasileira, onde as relações de poder tradicionalmente sempre se caracterizaram pela ilegalidade e pelo arbítrio ao qual a maioria da população deve submeter-se, as práticas autoritárias não são afetadas pelas mudanças institucionais, nem pelas eleições livres e competitivas. $O$ legado das transições políticas em muitos países, como o Brasil, é a persistência de um nível extremamente alto de violência ilegal e de conflito violento, sem intervenção do sistema judiciário na sociedade. A pretensão mais alentada, que estamos devolvendo numa pesquisa, é elaborar o conceito de "autoritarismo socialmente implantado" e aplicá-lo numa linha provocada com grande claridade por Guillermo O'Donnell; autoritarismo que não termima com o colapso das ditaduras mas que sobrevive às transições e sob os novos governos civis eleitos, porque independe da periodização política e das constituições.

\section{TransiÇĀo OU A FALSA PACIFICAÇÃo da VIOLÊNCIA}

Transição, passagem, mudança de um lugar ou estado ou ato ou conjunto de circunstâncias para outro. Quem já viveu sob uma ditadura ou regime autoritário não tem dúvidas, quando a opressão termina, de que efetivamente mudanças ocorreram. As liberdades políticas são restauradas, eleições são convocadas, a alternância no poder volta. Mas a democracia não está garantida. Especialmente porque as transições políticas não remetem, em questão, à transformação do Estado em sua relação com as classes populares naquilo que é mais crucial, o enquadramento, a normalização(1). Há apenas, como depois das revoluções do século XVIII, uma "idéia constitutiva" que agora pode vir a ser realizada(2). Impossfvel negar, no entanto, que a reconquista da democracia representativa constitui uma barreira importante ao poder do Estado, abrindo possibilidades para que as lutas e as resistências populares possam se materializar(3), aumentando suas condições de autodefesa.

Em muitos casos, como o Brasil, as transiçōes políticas foram incapazes de assegurar uma das pedras de toque da democracia, qual seja, o controle institucional da violência iłegal praticada pelas autoridades públicas. Algumas análises da transição, como as de José Ảlvaro Moisés, Guillermo O’Donnell, Philippe Schmitter, Thomas Skidmore, Alfred Stepan, não deixaram de chamar a atenção para essa continuidade da violência ilegal do Estado depois da suspensão da criminalização, da dissidência política que cessa. O retorno à formalidade da democracia com o final das transições políticas não implica que a partir desse momento aquela exista. O estado de direito, entendido como efetividade das garantias dos direitos fundamentais para a maioria da população, como após outras transiçōes na história brasileira, volta a ser uma mera referência ritual. As limitações de que padece o sistema judiciário não asseguram à maioria da população essas garantias do direito conquistadas e até alargadas pela nova Constituição.

Uma transição concebida como limitada às instituições da representação política poderia fazer supor que a guerra explícita das relações de poder do regime de exceção tenha sido suspensa e que, depois do final da ditadura, a relação entre as classes foi regularizada pelo retorno à cidadania política (mesmo que nominalmente para a maioria da população). A transição política parte de uma concepção das relações de poder localizadas no sistema de representação política, com pouca ênfase nos movimentos da sociedade civil, que na resistência à ditadura a todo momento punham em questão as condições de exerć́cio da violência. Como sabemos, essa pacificação das transições políticas é ilusória, se partirmos do princípio, como Michel Foucault, de que relações de poder nas sociedades atuais têm essencialmente por base uma relação de força: "E se é verdade que o poder político, acabada a guerra, tenta impor a paz na sociedade civil, não $\varepsilon$ para suspender os efeitos da guerra ou neutralizar os desequilibrios que se manifestaram na batalha final, mas para reinscrever perpetuamente estas relações de força, através de uma espécie de guerra silenciosa, nas instituiçōes e nas desigualdades econômicas, na linguagem e até no corpo dos indivíduos"(4). A transição política é apenas um episódio dessa própria guerra.

Os governos civis que saem da transição política, terminada a etapa da mobilização da dissidência e de crítica da ditadura, têm uma enorme dificuldade em transformar o discurso da lei que assegura a normalização e o controle. A prisão e todas as "tecnologias políticas" do exercício do poder não são afetadas. Ao contrário, na democratização se vêem muita vèz reforçadas, como demonstram as políticas de segurança pública colocadas em prática depois de 1983. Para combater o crime, por exemplo, continua-se a 
aprofundar e enrijecer os rituais meticulosos do poder - suspensão da lei Fleury para os criminosos primários, endurecimento por parte da magistratura, desrespeito da lei de execução criminal em nome da severidade. Nos países de tradição autoritária como o Brasil - sem ruptura com o antigo regime -, a aparente pacificação das transições políticas, a partir dos traços benevolentes do final da ditadura e da euforia da transição, mascara as verdadeiras limitaçōes, reproduzidas historicamente e agravadas, da democratização e da organização do poder.

\section{O LEGADO DO AUTORITARISMO}

Se afirmamos a continuidade sob a transição, parece evidente haver um legado do autoritarismo: as perguntas surgem quando começamos a perguntar o que compóe esse legado. Neste há, obviamente, um contingente de elementos da estrutura autoritária do regime de exceção imediatamente anterior, considerado na sua moldura institucional, legal, administrativa, em suma, o que foi chamado um dia de "entulho autoritário". Enfím, as leis de exceção, a constituição outorgada de 1967 , mais todos os atos institucionais posteriores que, aliás, prevaleceram, enquanto durou a primeira transição sob o regime de exceção, desde a eleição de Tancredo Neves e depois da posse de José Sarney até a promulgação da Constituinte de 1988.

Apesar da disposição por parte de vários parlamentares, o primeiro governo civil não desarmou por completo as estruturas do autoritarismo. Depois da derrubada da ditadura Vargas em 1945 ate a Constituição de 1946, jâ havia prevalecido o entulho do Estado Novo, o que permitiu ao governo Jcsé Linhares e mesmo ao governo Dutra utilizaremse gostosamente das leis de exceção (por exemplo para lidar com as classes trabalhadoras e as greves).

Mas esse é o legado imediato mais visível. Há outro legado mais remoto, mais ou menos atualizado, como toda a construção do Estado Novo: mesmo que o "entulho" institucional produzido pelos governos militares de 1964-85 tenha sido varrido, restaram resíduos autoritários de regimes de exceção anteriores, ainda que transformados, inseridos nas práticas sociais e nas ideologias. Vestígios óbvios, que nem vestígios são, mas presenças asfixiantes, como a legislação trabalhista ou o conjunto de práticas autoritárias, incorporadas à mobilização populista.

Essa ambigüidade tão presente nas duas faces de Getúlio Vargas (Pinheiro) permitiu que os grupos dominantes utilizassem, como mostrou Michel Debrun, em relação aos grupos dominados e em todos os níveis, as estratégias da "conciliação" e do "autoritarismo desmobilizador'(5). Cada vez parece mais relevante a instigante referência de Debrun à noção de arquétipos políticos e ideológicos, "uma modalidade de percepção global da sociedade, entrosada com certo estilo de atuação sobre ela, que pode ser encontrada em momentos históricos muito diversos'”(6). Se assim considerarmos, o legado autoritário, no nível ideológico e no nível das práticas, é extremamente flexível e transtormável.

Falar em transição nesse domínio é quase impossível porque as mudanças aqui são muito mais lentas do que a temporalidade das alterações formais-jurídicas dos regimes políticos e das instituições. Em vez de transições temos uma extraordinária continuidade: podemos ter mudanças no quadro político institucional sem que a cultura política, por exemplo, seja afetada. No âmbito da cultura e da ideologia o movimento de reprodução dos elementos do legado limita as possibilidades de transformação ou pelo menos elas não ocorrem seguindo o mesmo ritmo da periodização da reforma política. É muito complexo (quase impossível) colocar em prática projetos, por exemplo, de reforma cultural, e os ensaios realizados no Brasil resultam em alterações cosméticas. Muito ilustrativo a esse respeito é o destino das várias experiências de desnazificação nos países europeus examinadas por John $\mathrm{Herz}^{(7)}$, apontando todos os obstáculos e demonstrando as dificuldades para o tempo específico da evolução da cultura política seguir a transição política.

Ao enfrentar o problema das relações entre transição e controle da violência ilegal devemos investigar quais os elementos do padrão dessa violência que constituem um verdadeiro legado do regime de exceção, bem como apontar quais os elementos que podem ser explicados como conseqüência da reprodução da estrutura tradicional de dominação e de poder, levando-se em conta que muitos aspectos desse padrão são apenas reforçados pelos governos autoritários.

Para recuperar esses elementos é necessário que a avaliação das transições vá além
5 Michel Debrun, A conciliaçăo e outras estratégias. Săo Paulo, Brasiliense, 1983, p. 33.

6 Debrun, op. cit., p. 134.

7 From dictatorship to democracy. Edited by John Herz. Westport, Greenwood Press, 1982. Ver especialmente John Herz, "Denazification and Related Policies", Herz, p. 15-38. 
dos limites do Estado e das instituições políticas. Depois de Foucauit sabemos que a "tecnologia política" do corpo - o entrecruzamento das relações de poder com o saber e o corpo (remetendo para a questão da violência física) - não é localizável numa instituição somente ou num só aparelho de poder, a saber, o Estado ${ }^{(8)}$. A ênfase das análises da transição sobre as instituições estatais, prolongada pelo silêncio ou pela não consideração da violência ilegal, contribui para reiterar a tolerância diante do poder na proporção direta em que esse consegue esconder seus mecanismos ${ }^{(9)}$. Justamente nesses mecanismos de poder onde não ocorre nenhuma transição.

$\mathrm{Na}$ medida em que se tolera a dissimulação intensifica-se o mascaramento dos procedimentos disciplinares ilegais. Por exemplo, durante os governos estaduais diretamente eleitos e o primeiro governo civil (1985-89), logo renunciou-se - devendo ser ressaltado que em São Paulo, no governo Franco Montoro (1983-87), em grande parte graças às convicções e ao empenho quase solitários do próprio governador, tenha-se pela primeira vez na história política brasileira tentado impor mecanismos de autocontrole ao arbítrio do Estado - às exigências de uma efetiva reforma das instituições do direito e da justiça. Ainda que tenha havido progresso efetivo em termos de representação política, as práticas da violência ilegal ou pelo menos a tolerância em relação a elas continuam a impedir que a maioria dos membros da sociedade não se tornem iguais e com acesso aos recursos e mecanismo de poder ${ }^{(10)}$.

\section{O “REGIME DE EXCEÇÃO PARALE- LO'}

Durante toda a República no Brasil, as práticas repressivas dos aparelhos do Estado e das classes dominantes estiveram caracterizadas por um alto nível de ilegalidade, independentemente da vigência ou não das garantias constitucionais. Para os pobres, miseráveis e indigentes que sempre constituíram a maioria da população podemos falar de um ininterrupto regime de exceção paralelo, sobrevivendo às formas de regime, autoritário ou constitucional. Nesse regime político a ilegalidade a que estão submetidas as classes populares, as classes torturáveis, é muito mais larga do que aquela presente na aplicação da lei ou nas práticas policiais. Esse regime independe do regime político propriamente vigente, do regime constitucional: nenhuma das chama-

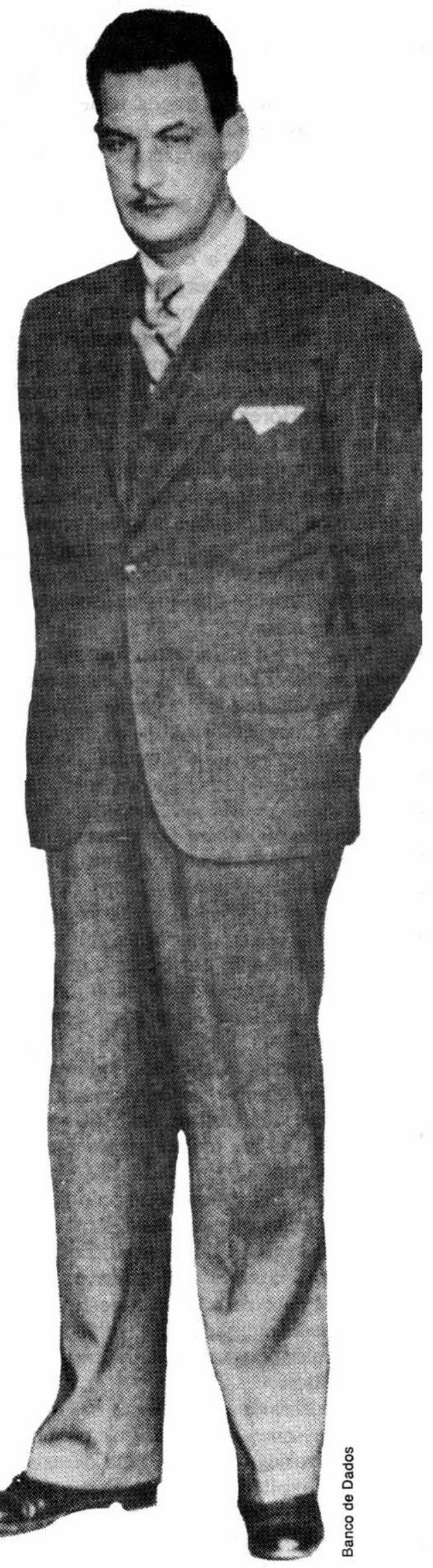


das transições democráticas, seja depois da ditadura do Estado Novo, seja depois das diversas ditaduras militares, de 1964 a 1985, afetou substancialmente este "regime de exceção paralelo", expressão inspirada nas observações de um operário holandês no Brasil sobre a aplicação da constituição, em 1925(11).

A descrição desse regime - construído contra a constituição, que para os donos do poder é sempre um obstáculo do qual precisam passar ao largo -, feita por esse sofisticado observador holandês, Joh de Bruin, há cerca de dezoito anos fora da Europa, membro da Allgemeiner Arbeiterverein (União Geral dos Trabalhadores, associação de orientação social-democrata fundada em São Paulo em 1892), prevalece até hoje: “A Constituição promete a nós, operários, muitas liberdades, mas... com o passar dos anos, foram criadas muitas leis que entram em conflito com o texto constitucional, que passou a ser letra morta"'(12). Toda "violência defensiva"'(13) é impedida pelos patrões e pela polícia atravês da violência física, da violência aberta. "Qualquer crítica exercida, falada ou escrita, sobre ações do governo brasileiro pelos operários, é considerada violação da lei. Qualquer propaganda, de boca a boca, espalhando o socialismo, é proibida, sob peıla de expulsão para o estrangeiro. Temos conhecimento de casos de expulsão de pessoas, após permanência de vinte e cinco anos neste país." E situa no contexto internacional o "regime de exceção" brasileiro: "Há cerca de três anos foi proclamado estado de sítio no centro do país. Vivemos sob ditadura policial, pior ainda que aquela da antiga Prússia, onde a censura de imprensa era aplicada com grande intensidade. Com o maior empenho se abre toda a correspondência que chega e que é mandada para o exterior; é tomado conhecimento do seu conteúdo, e o segredo das cartas é violado da maneira mais atrevida"(14). A lei constitucional permite o direito de reunião e de assembléia. Na prática, informada a polícia pelos patrões, que os operários planejam numa assembléia uma greve, a assembléia pode ser interrompida à força e confiscados os documentos, prendendo-se a direção da associação e proibida outra reunião ${ }^{(15)}$.

Nos períodos de democracia constitucional - sem que a Constituição implicasse a vigência das garantias do direito para a maioria - 1934-37 ou 1946-64 -, o regime de exceção paralelo ficou dissimulado porque a repressão física, ilegal, aberta, propriamente dita passou a ser coadjuvada por mecanismos de controle social mais sofisticados. Ao mesmo tempo em que se abrandava a taxa de expoliação, elevavam-se salários e punhase até em prática uma política de bem-estar, através dos mecanismos da previdência social. Nas fases de autoritarismo efetivo como na Primeira República ou de autoritarismo "legalizado", como na ditadura do Estado Novo e a partir de 1964 ate 1985, essa dissimulação vem abaixo: a necessidade de ajustar as contradições no interior dos grupos no poder justifica intensificar a repressão política que assegurasse o controle sem participação das classes populares, derrubando as fronteiras entre o exercício da repressão política e da repressão comum. Os organismos responsáveis por essa repressão passam a agir, sem limites, de acordo com as necessidades dos grupos dominantes. Assim, o autoritarismo desvenda na prática o que nas fases democráticas fica dissimulado: o caráter da repressão autoritária e os contornos da violência física ilegal.

O caso dos anos 1920 no Brasil é extremamente revelador. A repressão política às revoltas militares permite ao aparelho de Estado, utilizando-se do recurso ao "estado de sítio", que autoriza a suspensão das garantias constitucionais, aprofundar sua ação em duas direçōes perseguidas em períodos "normais", alargando seu âmbito. Em primeiro lugar, atingindo as organizaçãos operárias: não importa que a classe operária não tenha participado das revoltas políticas, e nem a repressão ao movimento operário surge com a perseguição aos movimentos militares. Simplesmente se abrem possibilidades alargadas fora de qualquer controle e logo legalizadas, incorporadas à estrutura do aparelho funcional do Estado (como a criação do DOPS, em 1924, por causa da revolução de 1924). Em segundo lugar, o regime de exceção legalizado (na ditadura ou no "estado de sítio") favorece a repressão ilegal aos criminosos comuns. Seja no estado de sítio em 1925, como graças à legislação de segurança nacional a partir da revolta comunista de 1935, durante a ditadura do Estado Novo entre 1937 e 1945: “A polícia fez deter, também, por essa ocasião, todos os malfeitores contumazes com inúmeras entradas no Depósito de Presos e alguns deles com várias condenações por crimes comuns praticados contra a propriedade, e cuja vida pregressa aconselhava, como medida de prudência, o seu isolamento do meio social"'(16). Essa mesma abrangência dos métodos do regime de exceção oçorre durante os governos militares entre 1964-85: o extermínio de suspeitos tem prolongamentos na transição política quando o policiamento ostensivo se militariza. Entre 1981 e 1989 foram mortos 3.900 suspeitos e criminosos em São Paulo, sendo
11 Tirei esta expressăo de Joh de Bruin, "Rapport over die arbeidens verhoridingen in Brasilien" (traduzido do holandês, Relatório sobre a situaçăo operária no Brasil), Såo Paulo, manuscrito, 1925, p. 24, Archives Albert Thomas, ABIT, do qual foram publicados trechos in Paulo Serrgio Pinheiro e Michael M. Hall, A classe operária no Brasil, Documentos, 1889-1930, vol, II (Sa Documentos, 1889-1930, vol. II (Săo Paulo, 1983), p. 316. Empreguei esta expressăo in "Repressão e insurreiçăo (comunistas, tenentes e violência do Estado no Brasil, 1922, 1935) e capítulo 5 "O enquadramento do movimento operário", pp. 238-78.

12 Loc. cit.

13 A expressăo é de Herbert Marcuse: Conversaciones con Herbert Marcuse. Jurgen Habermas y otros. Barcelona, Gedisa, 1980, p. 173.

14 Joh de Bruin, op. cit.

15 Boaventura de Souza Santos, num outro contexto, utiliza a expressão "Estado paralelo" para se referir às formas de Estado que toleram a vioformas de Estado que toleram a vio-
laçăo das leis, a aplicaçăo seletiva da lei, a năo regulamentaçăo da lei de modo a bloquear sua execuçăo. Ver seu luminoso $O$ Estado e a Sociedade em Portugal (1974-1988). Lisboa, Afrontamento, 1990, pp. 2248.

16 "O Estado de Sfrio e o Estado de Guerra (súmula feita pelo chefe de Polfcia)", Arquivo de Getúlio Vargas, vol. XXVI, documento 65. Apud Helio Silva, 1937. Todo os golpes se pare cem. Rio de Janeiro, Civilizaço Bracem. Rio de Janeiro, Civilizaçăo Bra-
sileira, 1970.

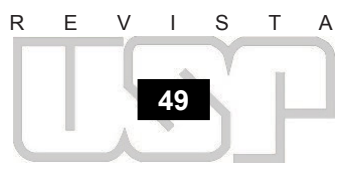


$80 \%$ desses abatidos na Grande São Paulo. Mesmo ponderando esses números com as taxas de criminalidade e os sucessivos crescimentos demográficos não há situação equiparável no mundo.

A repressão política "politiza" (perdoem-nos a redundância) a luta contra o crime, tornando cada vadio, "ladrões, assaltantes e arrombadores", prostitutas, menores nucivos, revolucionários ou dissidentes em potencial, inimigos internos. $\mathrm{O}$ regime de exceção strictu sensu unifica a luta contra o crime comum e o crime político na ação policial, com a diferença que para o primeiro o exame judicial continua nulo e para o segundo o procedimento jurídico requer mais sofisticação. Na realidade, naquela declaração acima, do chefe de polícia do ditador Getúlio Vargas, Felinto Müller, não havia grande diferença em relação ao discurso dos chefes de polícia da Primeira República quando defendem a vigilância, a prisão para prevenir, antes que a ação seja cometida. Parece uma reiterada ressonância daquelas dificuldades, alvo da reclamação de Heinrich Himmler, chefe da Gestapo, reclamação que iria levá-lo até os campos de extermínio, de que a lei criava entraves para a boa atuação da polícia, impedindo-a de fazer "muitas coisas (...) impossíveis nos termos estritos da lei escrita, mas autorizadas pelas leis do espírito e pela inteligência. Em muitos casos, evidentemente, a lei não me autorizava a prender um criminoso que nada tinha feito"(17). Prender para evitar, essa justificativa em relação à dissidência até quando se recue foi invocada. A pretensão da polícia no Brasil, de poder, com as mãos livres, recorrer a essas mesmas leis "do espírito e da inteligência" contra a lei positiva, as garantias constitucionais, será amplamente satisfeita com as "leis de exceção" que Joh de Bruin criticava na Primeira República. Mas durante outros perfodos constitucionais que se seguiram, com ou sem leis de exceção, o arbítrio marcará a prática dos aparelhos repressivos do Estado.

\section{AUTONOMIA E DISSIMULAÇĀO DOS APARELHOS REPRESSIVOS}

O acesso ao poder político das antigas oposições democráticas não implica a reforma da violência: o acesso dos partidos políticos democráticos, por eleições livres e competitivas, ao governo, não esvazia automaticamente a ilegalidade que caracteriza e marca o monopólio da violêncıa física legal pelo Estado, nem afeta a alta autonomia dos aparelhos policiais. Estes não são uma coisa, ou uma estrutura neutra em si: as relações que caracterizam o Estado impregnam sua própria estrutura ${ }^{(18)}$. Os aparelhos repressivos do Estado no Brasil estão impregnados do arbítrio, do terror e dos abusos das relações de poder. Os governos da transição trataram os aparelhos policiais como se fossem aparehos neutros capazes de servir à democracia e subestimaram o legado autoritário em suas práticas.

Nas transições, as destituições do pessoal policial e as transformações dos aparelhos da violência permanecem "nos limites de uma continuidade do Estado"(19): a depuração dos aparelhos estatais depende dos limites impostos pelas relações de força que assegura a transição. A própria presença de José Sarney como candidato a vice-presidente, a eleição indireta pelo colégio eleitoral e, depois, o acesso de Sarney à presidência mostraram às escâncaras esses limites. Os funcionários do Estado que praticaram a tortura ou aqueles que serviram à repressão ilegal (por exemplo médicos legistas que deram laudos falsos, delegados encarregados de providenciar o recolhimento de corpos de dissidentes políticos assassinados) continuam em função graças à anistia política.

As possibilidades de transformação da estrutura organizacional dos aparelhos de Estado (especialmente os encarregados da violência) são muitas, estreitas ou nulas na transição política. Assegurando a vigência do "regime de exceção paralelo", que se consubstancia numa rede estatal paralela, na formulação de Nicos Poulantzas (rede, porque atravessa os diversos ramos e aparelhos do Estado; paralela, porque funciona por trás da fachada dos aparelhos do Estado que a dissimulam cuidadosamente; estatal, porque geralmente para-pública), constitui um recurso permanente de que se valem os grupos dominantes para a manutenção e salvaguarda de seu poder ${ }^{(20)}$.

Assim, em vez de transição há uma continuidade no nível dos dispositivos disciplinares que une os funcionamentos de várias instituições de controle, e no nível dos próprios aparelhos; portanto, continuidade nas práticas e continuidade nos aparelhos. Como Guillermo O’Donnell(21) indicou, a transição política do regime autoritário não é obrigatoriamente uma transição democrática: ela não põe em questão a hierarquização, a ilegalidade da violência do Estado, o controle de autonomia dos aparelhos repressivos 
da ditadura ampliada pela ditadura. Há um agravante no caso brasileiro porque a Constituição de 1988 reiterou a organização dos aparelhos repressivos formulada durante a ditadura: a constituinte reescreveu o que os governos militares puseram em prática. Não há transição, mas plena continuidade. Dizemos agravados porque esses dispositivos disciplinares, essa ilegalidade, não foram criados pela ditadura. Esta simplesmente recorreu, de forma mais sistemática e intensa, às instituições da violência comumente utilizadas nos períodos constitucionais. No caso brasileiro, a repressão se reveste de conteúdos hierárquicos autoritários indispensáveis à reprodução das relações de poder (que a transição não põe em questão). $\mathrm{O}$ caso da proteção dos direitos humanos é emblemático para se entender essa compatibilidade entre continuidade das pautas ilegais de violência e transição: apesar das lutas de resistência durante a ditadura e a transição, os governos eleitos instalados não conseguem levar até as últimas conseqüências as exigências dos movimentos de direitos humanos formuladas, a princípio, em relação às dissidências políticas e, depois do final da ditadura, alargadas para toda a sociedade.

Os impasses da transição desvendam que essa autonomia dos aparelhos repressivos e as práticas da violência ilegal sobrevivem em níveis tais, não constatáveis em outras transições políticas na América Latina ou em alguns casos europeus, como a Espanha e a Grécia. Tanto a tortura como a eliminação de suspeitos e outras práticas rotineiras da "pedagogia do medo", sistematicamente aplicadas às classes populares (invasões de domićlio, operações sweeps de limpeza das ruas, espancamentos, seqüestros, assassinatos no campo, massacres), são toleradas. $\mathrm{O}$ discurso oficial na maior parte das vezes ostenta um repúdio retórico que não se traduz em nenhuma ação concreta, consagrando a impunidade para a violência ilegal. A saber, as mesmas práticas que durante o período autoritário suscitavam protestos, marchas, manifestações - quando os atingidos eram indivíduos provenientes das classes médias e da burguesia. Na atual transição, como em outros períodos passados de normalidade política, crê-se que, contra as classes populares e os criminosos, esses métodos, repudiados durante a ditadura, podem sobreviver como plenamente justificados.

A política da segurança pública, repetimos, nas suas linhas mais gerais e na maior parte dos estados durante os dois governos da transição política, continua sendo a mesma da violência explícita e ilegal da ditadura. $\mathrm{O}$ combate contra o crime comum segue as linhas convencionais e anteriores à ditadura, enriquecidas pelas ilegalidades agregadas durante esse período, como a militarização do policiamento ostensivo, aliás, consagrado pela Constituição de 1988. O Estado brasileiro jamais renunciou a nenhuma das "conquistas" - desde o cassetete de borracha, passando pelo "pau-de-arara", até a bateria para choques elétricos - no que diz respeito à ilegalidade da violência dos regimes autoritários.

A autonomia no funcionamento dos aparelhos repressivos depois da transição é dissimulada pelo discurso democrático que não consegue intervir nessas pontas das práticas da violência ilegal. Os governos democráticos da transição após 1985 foram incapazes de alterar essa situação porque fizeram de conta que essa coerção fundada em sua maior parte na ilegalidade ou na não-legalidade poderia ser modificada através da mudança da política nos centros de poder. Enquanto não houver um reconhecimento da localização das relações de violência, onde e como elas efetivamente ocorrem, nenhuma 
política de reforma é possível, pois a dissimulação e um atributo necessário das relações de poder, como lembra Bordieu ao propor que "o caráter específico de toda relação de força é dissimular-se como tal, e adquirir toda a sua força porque é tão dissimulada"(22). A transição política para uma democracia somente é possível quando, a essa dissimulação da repressão ilegal, a sociedade impõe a transparência - algo que o discurso liberal tradicional dos governos estaduais eleitos depois de 1983, ou o governo civil federal eleito pelo colégio eleitoral em 1985, não quiseram ou não tiveram condições de realizar.

Devemos levar em conta que os aparelhos repressivos, que se articulam nessas "instituições da violência", funcionam com larga autonomia, não como uma disfunção. Funcionam desta maneira porque essa é a concepção do poder, a concepção da disciplina. A democratização do governo não implica automaticamente na hegemonia dos princípios da democracia no funcionamento do aparelho repressivo. Como se a reforma do discurso político ou da ideologia política pudesse magicamente transformar as relações de poder. Porque elas não estão somente nos centros da cena política, mas estão também lá embaixo, lá longe, nas extremidades, nos microcontextos, onde ocorrem as relações concretas entre as classes, os grupos sociais, seus interesses. Quem faz a atribuição concreta da justiça, no enfrentamento do crime comum, não é o juiz mas o agente penitenciário, os carcereiros; quem garante a segurança não são os corpos policiais considerados nas suas grandes estratégias (quando têm), ordenados e dentro dos seus regulamentos, mas a polícia civil nas delegacias e a polícia militar nas ruas. O que conta para a imposição da democracia nos aparelhos da violência são as modificações nas interrelações concretas, nas pontas dos tentáculos dos aparelhos do Estado. Mas parece evidente, insistimos, é que essa dissimulação e outras dimensões propriamente institucionais do "regime de exceção paralelo" não poderiam subsistir se não contasse com algum apoio e legitimidade no interior da sociedade.

\section{VIOLAÇŌES AUTORITÁRIAS E ESTADO DE DIREITO}

Um dos traços da especificidade do caso brasileiro é a extraordinária longevidade da cultura e das práticas autoritárias, independentemente, como já dissemos, da transformação do regime polf́tico ou da complexidade crescente da sociedade. Parece haver no Brasil um peso determinante do passado(23). Como disse a escritora Elizabeth Hardwick, que visitou o Brasil em meados dos anos 1970, durante a ditadura Geisel: "Os séculos parecem habitar cada momento; os diamantes em minas, os navios negreiros, Dom Pedro em seu palácio de verão em Petrópolis, a tradição liberal, os terroristas, a polícia, Vargas, Kubitschek, os jesuítas. Tudo existe num contínuo presente, uma consciência superpovoada e dada à fadiga."(24).

A estrutura do poder que tem prevalecido no Brasil durante todo o século XX pressupõe a negação dos direitos da maioria da população para que o sistema de exploração possa ser reproduzido sem acidentes maiores: a transição política é um episódio soft que não afeta esse sistema hard de exploração. Meditando sobre a obra de Florestan Fernandes, Gerard Lebrun mostrou que nunca houve aqui uma ruptura com o antigo regime: o absolutismo colonial se transformou simplesmente no absolutismo das elites. E sobreviveu à abolição da escravidão uma total assimetria entre dominador e dominado: "A ordem civil se transforma, mas de modo tão desigual, desarticulado e ambíguo que o 'patrão' conserva muito de 'senhor' em sua condição de cidadão, e o trabalhador (livre ou semi-livre...) é um cidadão de categoria tão ínfima que possui algo de 'escravo' em potencial e muito pouco de cidadão..."(25). Para caracterizar essas práticas das classes dominantes poderíamos recorrer à síndrome do poder autoritário descrita por Primo Levi: "uma visão distorcida do mundo, arrogância dogmática, a necessidade de adulação, a compulsão por estar nas alavancas de comando, e desprezo pela lei"(26).

Especialmente desprezo pela lei. No Brasil a lei jamais serviu para inibir o arbf́trio das ações dos governantes. Nunca houve grande diferença, sempre tomando por referência a maioria da população: pobre, miserável, indigente, negra ou mestiça, durante o período republicano, entre o poder do arbítrio extra-legal e o rule of law, entendido aqui como aquela imposição de inibições efetivas sobre o poder e a defesa do cidadão das imposições do poder. E essa situação aparece com mais nitidez nas transições políticas brasileiras depois da Segunda Guerra Mundial. No Brasil, nem os períodos constitucionais nem as transições jamais inibiram o uso da violência ilegal (prisões arbitrá- 
rias, emprego corriqueiro de forças policiais contra as multidões, tortura e execuções sumárias) contra a sociedade. No Brasil, democracia e transição democrática jamais inibiram a prática da violência ilegal. Recentemente, um cientista político, Philippe Schmitter, dizia que "não existe no mundo párs com instituições democráticas que viole tanto as suas próprias leis quanto o Brasil. É o descontrole do Estado"(27).

Ao contrário de outros países, onde as revoluções burguesas do século XVIII deram origem a instituições capazes de controlar ou submeter os abusos daqueles que detêm 0 poder, aqui a lei serviu univocamente como expressão de dominação sem oferecer nenhuma garantia do exercício de direitos fundamentais para a maioria da população. Não se pretende ocultar o fato de que mesmo naquelas sociedades o direito mediava as relações de classe existentes em favor dos governantes através de formas legais. Mas no Brasil a lei, além de dissimular as relações de força, jamais limitou as incursões do poder(28).

Como na feliz metáfora de Alain Rouquié, estamos aqui diante de uma verdadeira “cultura política en trompe l' oeil 'onde' as falsas janelas do universalismo jurídico ali recobrem o particularismo das relações pessoais e de força"(29).

Apesar da sofisticação progressiva da violence douce de todos os controles sociais, dos controles ideológicos progressivamente postos em prática, estes não afetaram nem transformaram a violence ouverte. Se fosse preciso formular em termos de postulado poderfamos propor que o Estado brasileiro jamais renunciou a nenhuma das "conquistas" efetuadas no campo da violence ouverte, especialmente aquelas criadas nos periodos de regime de exceção propriamente dito, os refinamentos da tortura convivendo até hoje com suas versões mais primitivas até as execuções sumárias e linchamentos. Estando claro que a violence symbollique somente é efetiva através da ameaça permanente e do emprego legal, não-legal ou ilegal da violência aberta: no sentido, apontado por Alf Lütdke de que as duas formas de violência estão ligadas intrincadamente, "as diferentes formas de violência simbólica para os dominados incluem sempre a experiência assim como a antecipação da violência física 'de cima'. A violência simbólica não é o oposto mais racional ou moderno da força física mas, ao contrário, ela somente se torna efetiva pela presença permanente da violência bruta que ela simboliza"'(30). Talvez devêssemos voltar à discussão da formação do monopólio da violência no Estado colonial brasileiro para entendermos essa permanência. Aprendemos com Norbert Elias que o estabelecimento do monopólio militar e policial no Estado em geral dá lugar à criação de espaços pacificados nos quais o emprego da violência ocorre como exceção. Ora, aqui a violência continua a ocupar a cena, como regra. "A ameaça física que pesa sobre cada um é menos impessoal: paradoxalmente à modernização do Estado e de seu aparelho repressivo, a organização monopolista da coerção física age sobre a maioria da população como uma ameaça direta"(31).

O caso do Brasil mostra que o autoritarismo e o arbítrio podem persistir apesar da abertura democrática, das eleições e da reforma constitucional. A tortura sistematicamente administrada persiste nas delegacias de polícia em todo o país, independentemente do grau de desenvolvimento socioeconômico dos estados. Podemos formular o paradoxo segundo o qual número diário de torturados depois da transição política excede milhares de vezes os números diários de torturados políticos durante os vinte anos da ditadura: não há comparação possível entre as torturas regularmente realizadas contra todos os suspeitos e criminosos (desde que pobres, mulatos ou negros) nas delegacias do Brasil inteiro e as câmaras de tortura dos organismos paralelos durante a ditadura. Durante o ano de 1990 ocorreram ainda pelo menos quatro casos de tortura a soldados em instalações militares, como o caso em Anápolis. De 1981 a 1989, a Corregedoria da Polícia Civil em São Paulo registrou 259 casos de torturas denunciados, envolvendo 580 policiais (dos quais 362 foram absolvidos...). Os abusos físicos e as ilegalidades permanecem impunes em praticamente todas as prisões do país, com largo assentimento por parte da sociedade. Em São Paulo, mais de 3.000 presos, ou seja, cerca de $10 \%$ dos encarcerados, aguardam julgamento e cumprem pena em xilindrós de distritos policiais.

A morte violenta é uma ocorrência comum, e larga proporção dessas mortes, mesmo depois do final do regime militar, continua a ser atribuída aos esquadrões da morte (como em Pernambuco, no Espírito Santo ou no Rio de Janeiro) e a grupos de justiceiros (na periferia de São Paulo estima-se em mais de duzentos os bandos de extermínio, muitas vezes financiados pela comunidade e por comerciantes). Na cidade de São Paulo, entre janeiro e agosto de 1990, 300 pessoas foram assassinadas por justiceiros. Em pelo menos quinze estados brasileiros, esses esquadrões da morte são os principais res-
27 Philippe Schmitter, "Condenados à democracia", in Jornal do Brasil, Caderno Especial, 10/7/1988, p. 10.

28 E. P. Thompson, "The rule of law", in Whigs and hunters. Middlesex, Penguin, 1977, Pp. 264-5. Ver tomber Wuin tamberm Drometida (Rol, Jordna, Roll). Rio de Janeiro, Paz $\Theta$ Terra, 1988 (especialmente "A funçăo hegemónica do direito", pp. 48-76).

29 Alain Rouquié, Amérique Latine. Paris, Seuil, 1987, p. 113.

30 Alf Ludtke, "The State and social domination in eighteenth and nineteenth - Century Prussia", in Raphael Samuel (ed.), People's history and socialist theory. London, Blackwell, 1981. P. 105. Ver tamberm a versa mais extensa do memo role of state violence in the period of transition to industrial capitalism: the example of Prussia from 1815 to $1848^{\circ}$, in Social History, vol. $4, n^{2} 2$, may/1979, pp. 175-221. Ver Pierre Bourdieu, Les modes de domine tion" in Actes de la Recherche inciche en sciences sociales, 2-3, $2 e$ année, juin/1976, pp. 122-32, para a distinçắo violence douce ou violence symbollique e violence ouverte.

31 Norbert Elias, "Violence and civilization", in Keane, op. cit., pp. 177-98.

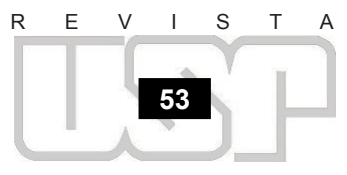




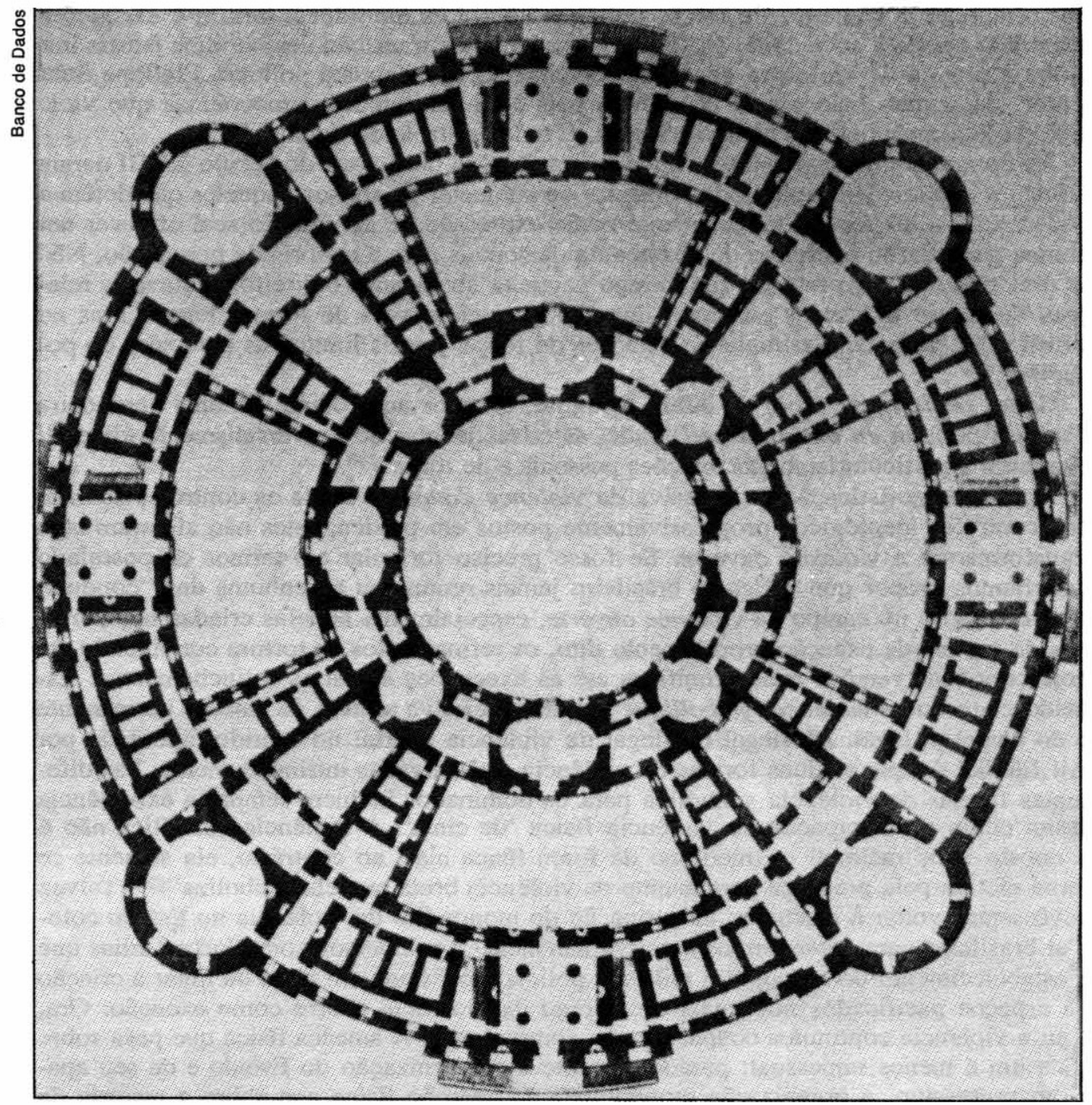

Projeto de Prisão, de J. F. de Neufforge; consta do livro Vigiar e punir, do francés Michel Foucault (Ed. Vozes)

ponsáveis pela morte de menores nos primeiros seis meses de 1990: foram assassinadas 62 crianças e adolescentes (nos doze meses de 1989, foram registradas 65 mortes). Encre 1984 e julho de 1989 foram contabilizados 1.397 assassinatos de crianças e adolescentes. Segundo levantamentos da Comissão Pastoral da Terra, em 25 anos entre 1964 e 1988 , houve 1.501 assassinatos, sendo que mais dois terços nos anos 1980, aqueles da transição política. Apesar dessas impressionantes cifras, houve somente quatorze processos de acusação e somente seis condenaçōes.

O mais alto nfvel de mortes envolvendo o aparelho policial entre todos os países do mundo com constituição democrática continua a ocorrer em São Paulo. A cifra de 589 mortes de suspeitos e criminosos pela polícia militar em 1989 equipara-se com a totalidade de mortes em conflitos com a polícia em um ano em todo o território dos Estados Unidos (com uma população quase dez vezes maior do que a de São Paulo e com efetivos policiais cinco vezes maiores). Entre 1979 e 1989, mostrou José de Souza Martins $^{(32)}$, ocorreram 272 casos de linchamento: desses, 136 ocorreram durante o governo civil, depois da ditadura, entre 1985 e 1989. E o dado mais preocupante é que 131 casos ocorreram no Estado de São Paulo. Não existe nenhum regime democrático no mundo que apresente, como o Brasil, com altíssimos índices de violência criminal, tais índices de violações de direitos humanos e impunidade.

Não é por acaso que o Brasil está em segundo lugar, lodo depois da Colômbia, quanto ao número de defensores de direitos humanos assassinados em 1989, segundo levantamento de Americas Watch. $\mathrm{O}$ retorno a um governo civil não-autoritário e a um governo legitimamente eleito em 1989 não constituiu garantia para o respeito aos direitos humanos e para a consolidação do estado de direito para a maioria da população. Durante a transição política pretendeu-se estender as exigências de garantias dos direi-

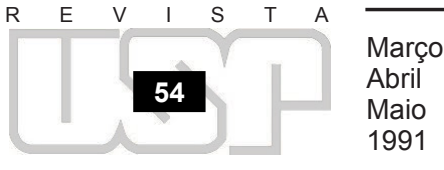


tos civis, anteriormente advogadas para os dissidentes políticos, para as classes pobres, miseráveis e indigentes. Essa transferência da defesa dos direitos humanos de uma minoria (em grande parte branca e de classe média) de ativistas e militantes - defesa que contava com o respaldo de uma ampla coalizão de simpatias e apoios na sociedade - para a defesa dos direitos humanos da maioria da população (mulatos, negros e das classes populares) esbarra na própria estrutura das relações de poder. A afirmação ampliada desses direitos ameaçava (ou assim era percebida pelas classes médias e classes dominantes) a institucionalização das regras de dominação( ${ }^{(33)}$ por colocar em risco os sistemas de hierarquia que historicamente prevaleceram na sociedade brasileira, assegurando a assimetria entre dominador e dominado.

\section{O "AUTORITARISMO SOCIALMENTE IMPLANTADO"}

Essas indicações referentes aos desenvolvimentos ocorridos na sociedade civil após o final da ditadura militar indicam resistências estruturais que exigem pesquisas além do sistema político strictu sensu. Era razoável supor, tendo em conta justamente a evolução histórica do Brasil, que a alteração ao nível do regime político não poderia implicar quase por reflexo a desmontagem dessas resistências, dessas estruturas autoritárias que independem do regime político. Depois do final da ditadura, os grupos na sociedade que pretendem aprofundar a democracia, concretizando o rule of law, as garantias dos direitos humanos, se reencontram, com a agravante de estarem mais isolados do que no período em que se desenvolveram, depois de 1964, com o padrão elitista, autoritário e hierárquico na sociedade brasileira. Tudo indica que os governos autoritários foram tão bem sucedidos, por um período tão largo, ao simplesmente exacerbarem, com sustentação social, certos elementos autoritários presentes na cultura política no Brasil. Para entendermos essas resistências nós acreditamos que a abordagem deva se deslocar das instituições políticas para as microdimensões do poder, as microcenas onde as interações concretas e violentas entre as pessoas têm lugar; dos microdespotismos que sobrevivem ao autoritarismo das ditaduras. No caso brasileiro predomina o que se poderia chamar de um "autoritarismo socialmente existente" que precede e ultrapassa os regimes políticos autoritários e independe da periodização da história política. Devo a inspiração para esta expressão a Guillermo O'Donnell na sua observação de que “talvez porque o autoritarismo está tão 'socialmente' implantado no Brasil, o aparelho estatal foi e sobretudo apareceu tão poderoso e decisivo, e acaparou tanto a encenação dos grandes episódios da vida nacional"(34). Parece estar inscrito numa grande continuidade autoritária que marca a sociedade brasileira (e sua "cultura política") diretamente dependente dos sistemas de hierarquia implantados pelas classes dominantes e reproduzidos regularmente com o apoio dos instrumentos da opressão, da criminalização da oposição política e do controle ideológico sobre a maioria da população.

Esse autoritarismo socialmente implantado tem suas raízes mais profundas do que as práticas determinadas pelos regimes de exceção. As análises políticas da transição não conseguem dar conta desse autoritarismo socialmente implantado, porque as relações de poder não estão somente incrustadas nas instituições macropolíticas. Se na transição as relações de força entre as classes dominantes se alteram - especialmente no âmbito da representação - as relações de poder assimétricas no interior da sociedade não são modificadas. O que nos obriga a analisar a transição através das micropráticas do poder, intocadas pela transição. Para tanto importa registrar e reconstituir a atuação concreta dos agentes nos microcontextos onde a relação de poder ocorre, deslocando-nos da cena política e dos órgãos de representação formal. Pois o comportamento dos agentes não está sincronizado com o tempo da abertura política (assim como os aparelhos do Estado: consideremos por exemplo o massacre dos dezoito presos mortos por asfixia dentro de uma cela do $42^{\circ}$ - Distrito Policial em São Paulo com cinqüenta e um presos em fevereiro de 1989). E se a concepção de poder se desloca das instituições políticas para as práticas culturais específicas, da mesma forma que não pode haver uma teoria geral do poder, impossível também uma teoria da transição capaz de dar conta da mudança ou continuidade em nível micropolítico. Daí a necessidade de se levantar, repertoriar, classificar as práticas autoritárias a partir da transição política iniciada em 1985 . Não é por acaso que a cidadania no interior das classes populares é ainda hoje percebida com significado aproximado à repressão, o que não constitui traço original nas sociedades contemporâneas, mas que no Brasil atinge uma enorme intensidade porque há grupos que não são apenas desprovidos de poder, mas de significação, como possuidores de
32 "Inchamentos: a vida por um fio", in Travessia, Revista do Migrante. Săo Paulo, Centro de Estudos Migratórios, II (4), março-agosto, pp. 21-7.

33 Henri Laborit, La Nouvelle grille. $\mathrm{Pa}$ ris, 10/18, 1974, p. 184.

34 Guillermo O'Donnell, " 'E eu com isso? Notas sobre a sociabilidade polftica na Argentina e no Brasil", in G. O'Donnell, Contrapontos. Autoritarismo e democratização. Săo Paulo, Vertice, 1986, p. 141. Para a noçăo Vértice, 1986, p. 141. Para a noçãá em Oscar Oszlak "Democracia en la Argentina: micro y macro", in Oscar Oszlak (org.), Proceso, crisis y transición democrática. Buenos Aires. Centro Editorial de Amśrica Latina, Contrina, Antei essa sugestăo do "autoritarismo socialmente existente", $\theta$ depois, lendo O'Donnell, "autoritarismo socialmente Implantado" em minha tese de livredocência Insurreiçăo e repressăo (comunistas, tenentes a violoncia do Estado, Săo Paulo). FFLCH, 1987. passim. Logo depois, em exposição passim. Logo depois, em exposiçăo des da redemocratizaçăo no Brasil", Seminário Século XXI, Unicamp. Campinas, SP, 7/7/1988, coordenado por Luciano Martins. Agradeco seus comentários comentarios ção Tavares e Philippe Schmitter. Nesse mesmo ano constitul no Nácleo de Estudos da Violência, o grupo de pesquisas sobre o "autoritarismo socialmente implantado". Retomel o tema em "Violence de l'Etat et Dissidende Politique (lo iEtat of Disside Brésil, 1929-1935) in P. S. Pinheiro, Colloque sur le crime politique, International Association for the History of Crime and Criminal Justice, 2-3, Paris, Juin/1989. Ver P. S. Pinheiro, "Autoritarismo depois da ditadura", in Tempo e Presença, $\mathrm{n}^{2}$ 246. S5o Paulo, outubro/1989, pp. 4-5. Sobre microdespotismos, ver P.S. Pinheiro (com Emir Sader), "O controle da po(ifcia no processo de transiçắo demoIfcia no processo de transiçăo demo-
crática no Brasil", in Temas IMESC, 2(2). São Paulo, 1985, pp. 77-95.

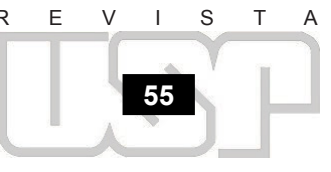


uma identidade coletiva conhecida: trabalhadores, pobres sem atividades fixas, miseráveis, indigentes, mulheres, velhos, crianças, negros, homossexuais, loucos, crimino$\operatorname{sos}^{(35)}$. Essa violência disseminada tanto na violência ilegal do Estado, como já vimos, contra a maioria da população, tem suas origens em práticas anteriores, por exemplo como aquelas que se forjaram durante a implantação do regime colonial e na ordem escravocrata. Como Maria Sylvia de Carvalho Franco já havia apontado precursoramente, na sociedade brasileira opera um sistema de valores que sanciona sua expressão violenta, "uma moralidade que incorpora a violência como legítima e a coloca mesmo como um imperativo, tendo efetividade e orientando constantemente a conduta de vários setores da vida social''(36). Para o que deve ter contribuído o fato de o Brasil se configurar, como lembrou Florestan Fernandes ao refletir sobre a violência, "um caso histórico extremo de coexistência entre um regime de classes muito desigual e rígido, de alta concentração da violência institucionalizada e orgânica no 'topo' e de elevadíssima rarefação concomitante (...) da violência institucionalizada entre os 'de baixo' com forte adensamento da violência 'anômica' e inorgânica da massa da população pobre e oprimida, largada a si mesma pela ordem civil constituída para proteger e unir, se possível, os membros dos estamentos privilegiados ou, mais tarde, das classes altas ou intermediárias, e praticamente cega à sorte dos deserdados postos a "cozer em seu próprio caldo'(37).

As violações tradicionais dos direitos civis (mesmo quando assegurados pela Constituição) praticadas pelas autoridades articulam-se com o desrespeito dos direitos civis no interior das relações interpessoais. $\mathrm{O}$ autoritarismo socialmente implantado é a interiorização dos métodos impostos à força (ou doucement) pelos grupos no poder que corroboram para restringir a representação e limitar as condições da participação política: “O regime de exceção paralelo não poderia subsistir se não contasse com largo apoio e legitimidade no interior da sociedade, inclusive por parte daqueles que são as principais vítimas da violência ilegal. A tortura, a eliminação de suspeito, enfím, as práticas rotineiras de uma 'pedagogia do medo' sistematicamente aplicada às classes populares (invasões de domić́lio, batidas nas cidades, espancamentos, seqüestros, massacres, chacinas) são visualizados como integrando a normalidade da maioria das populações. Se nas classes governantes e educadas o discurso oficial ostenta um repúdio retórico a essas práticas, ele não se traduz por ações concretas - por exemplo: fortalecimento das estruturas do judiciário - que coíbam esses abusos, consagrando-se a impunidade para a violência ilegal, tanto por parte dos aparelhos do Estado, tanto como nas interações entre os cidadãos'(38).

Para se compreender os percursos através dos quais o autoritarismo socialmente implantado é engendrado - desde aquelas longínquas origens históricas - e se reproduz, é essencial reconstituir a rede de microdespotismos nos mais variados contextos sociais: violência familiar, discriminação racial, violência contra a mulher e a criança, justiceiros, linchamentos. Padrões autoritários que podem estar nas "pequenas autoridades" que se aperfeiçoaram e se desenvolveram nos períodos de ditadura. Desde os almoxarifados de fábricas até as portarias de edifícios (controladas pelo DOPS através dos porteiros que estavam obrigados a remeter fichas sobre os moradores); essas pequenas autoridades interiorizaram e adaptaram a microcontextos o padrão de opressão difundido pelo macropoder. O "você sabe com quem está falando?" se difundiu em todas as interlocuções. O mito da democracia racial continua soberano, servindo como excelente dissimulação para uma vasta gama de microdespotismos exercidos contra o negro. Nunca foi necessário no Brasil institucionalizar um sistema de apartheid legal, porque, além da discriminação social e econômica, as "pequenas autoridades" e o sistema do "sabe com quem está falando" sempre desempenharam um papel de contenção dos negros na sociedade civil. As crianças negras crescem dentro das balizas desses microdespotismos e da interiorização dos limites impostos pela sociedade dos brancos. Além das formas de violência ilegal, a violência doce (nem sempre) dos preconceitos e das discriminações compõe o autoritarismo socialmente implantado.

No momento em que o autoritarismo socialmente implantado esteja menos dissimulado estarão abertas as portas para que - juntamente com o esforço de se superar as imensas desigualdades sociais e econômicas - uma verdadeira democratização possa vir a ser consolidada. A transição política para a democracia somente se tornará efetiva a partir do momento em que a desmontagem dessa intrincada rede de microdespotismos a que estão historicamente submetidas as classes populares na sociedade brasileira seja desvendada. 